\title{
PERSONAL LEARNING OBSTACLES AND THE ADOPTION OF ICT AMONG FEMALE STUDENTS IN SELECTED PUBLIC SECONDARY SCHOOLS IN OGUN STATE, NIGERIA
}

\author{
Tayo O. George ${ }^{1 *}$, May U. Orbih ${ }^{2}$, Olawale Olonade ${ }^{3}$, Anthony Onwumah ${ }^{4}$, Temilorun \\ Olaonipekun $^{5}$ \\ ${ }^{1} \mathrm{PhD}$, Department of Sociology, Covenant University, Nigeria, \\ tayo.george@covenantuniversity.edu.ng \\ ${ }^{2}$ M.Sc. Candidate, Covenant University \\ ${ }^{3} \mathrm{PhD}$ Candidate, Covenant University, Nigeria \\ ${ }^{4} \mathrm{PhD}$, Independent Research, Nigeria \\ ${ }^{5}$ M.Sc. Candidate, Covenant University, Nigeria \\ ${ }^{*}$ Corresponding Author
}

\begin{abstract}
Adoption of Information Communication Technologies (ICT) varies from one individual or group to yet another. Several factors contribute to the use and adoption of ICT among different segments of the society ranging from age, sex, cultural norms, environment, perception and interest in ICT This study attempt an empirical investigation of personal learning obstacles to adoption of ICT by female students in selected public secondary schools in Ogun State, Nigeria. The study seeks to examine obstacles female secondary students face in learning and adopting ICT studies. It attempts to identify the ICT usage and adoption strategy by female secondary school students with a view to establish existing relationships among these concepts. The study engages survey of selected public secondary schools in the region and in-depth interview of relevant stakeholders for the primary data. The study findings anchored on existing literature, relevant theoretical positions and data from statistical analyses reveal that majority of the female students use computers on rare occasions It concluded that Government should ensure that ICT facilities are provided to public schools in addition to implementing. ICT policies to eradicate personal learning barriers associated with the use of computers
\end{abstract}

Keywords: Females, Students, Information Communication Technology (ICT), Public, Secondary, Schools, Nigeria

\section{INTRODUCTION}

Information and Communication Technology (ICT) refers to the combination of computer and telecommunication systems. ICT includes the knowledge and skills required for the use of technology as a tool (George \& Suleiman 2015). Adoption Information communication technology (ICT) has become very 
important in today's life. The necessity is as a result of its functionality and efficiency in enabling individuals develops and advances in their professional occupation (Hashim, 2008). The education institution just like other major sectors in the society is already utilizing the capacity of information technology to improve the quality of life (Nwokocha, 2016). Also, ICT has played a major role in the field of education in enhancing teaching, researching and learning outcomes (Damkor, Irinyang \&Haruna, 2015). Previous studies have been conducted on the impact of the role of ICT in enhancing educational performance. In Nigeria, Nwokocha (2016) elicits the huge potential in the use of ICT skills and knowledge to facilitate accessibility of girl-child, as well as increasing girl-child interest in science and technology and entrance to knowledgebased society. Olulebe (2006) ascertained that ICT can expedite students' learning processes, provide opportunities and enhance economic. However, most secondary schools are facing couple of challenges adopting ICT-related studies which is as a result of dearth of interest of female students in ICT related studies, lack of basic infrastructure and gender inequality (Odukoya, 2005; George, Ahmadu \& Chukwudozie, 2013, George).

Without any doubts, ICT has become the agent of all innovations that has taken over all spheres of the modern societies (George et al., 2013). In a bid to move ahead in the 21st century, the Nigerian government inculcated ICT studies in the primary and secondary schools' curriculum to ensure ICT-savviness amongst students (Nwokocha, 2016). However, the under representation of girl-child in ICT related careers has been assumed to be as result of their perception rather abilities (Trauth, 2003; Odukoya, 2015; Nwokocha, 2016). Previous studies have been conducted to examine the impact of the role of ICT to enhance educational performance, to understand the use of ICT skills and knowledge, and to facilitate accessibility of girl-child, as well as increasing girl-child interest in science and technology and entrance to knowledge-based society (Odukoya, 2005; George, et al., 2013; Nwokocha, 2016).

In the process of narrowing the focus of the study, the study with a greater understanding seeks to examine the learning obstacles and adoption strategy associated with ICT usage among female secondary students. Therefore, the purpose of the study is to examine the personal learning obstacles and adoption strategy associated with ICT usage among female students in public secondary schools in Ogun state, Nigeria.

\subsection{Research Objectives}

In a bid to understand the influence of ICT in influencing the girl-child education, the aim of the study is to empirically examine obstacles female secondary students faced in learning and adopting ICT studies. Specifically, it attempts to identify the ICT usage, ICT adoption strategy and establish relationship among these concepts.

\subsection{Research Questions}

Based on the research objectives, the following research question is aimed at:

1. Examining the personal learning barriers associated with ICT studies among female students

2. Identifying the adoption strategy associated with ICT studies among female students

\section{LITERATURE REVIEW}

A good number of scholars have argued that the integration of ICT in education would lead to something positive (Adomi \&Kpangban, 2010; Ajayi \& Ekundayo, 2009; Nwokocha, 2016). As a result, this, Nigeria included computer education in both primary and secondary school curriculum so as to build on the formative stages of child's development to inculcate the ICT skills necessary to function in the era of globalisation. ICT has known to be far more beneficial to students as it enables them get access to resources not available in their school.

In Nigeria, studies have shown ICT adoption in secondary schools in Ogun state. Several researchers blamed the low level of ICT adoption among secondary school to decreased level of students' interests, lack of proper maintenance culture, dilapidated infrastructural facilities, epileptic power supply, nonimplementation of national ICT policy, limited funding to employ qualified and highly skilled ICT professionals and poor management (Adomi \&Kpangban, 2010; Ajayi \& Ekundayo, 2009). Furthermore, few studies have been able to show the importance of ICT studies on secondary school students in Ogun state. Ogundiile et al. (2019)'s study conducted a survey of 300 public and private secondary schools in Ogun state. The study addressed the factors that influenced ICT adoption in secondary schools and established that assistance, availability, cognitive factors are associated with ICT adoption among secondary school students in Nigeria. Also, another study which focused on the impact of ICT on the study habits of students in Iganmode Grammar School, Ota, Ogun state (Ilo et al., 2018). The study revealed that ICT improves the study habits of 
student.

The gains of ICT on the girl-child education cannot be overemphasized, as the ICT is a valuable strategy that seeks to enhance girl- child accessibility to education through online learning programmes (Nwokocha, 2016). Nwokocha (2016) further stated that the three contributions of ICT to the girl-child education which include access, quality and functionality. For instance, these contributions are useful to female who lack access to quality education due to several socio-cultural factors and security issues. According to Olubebe (2006), ICT should be incorporated in schools as its enrich, motivates, deepened and enhances student's skills and learning processes, for the girl-child, ICT exposes and increases their access to health, education and other developmental opportunities. However, lack of ICT trainings poses a serious barrier to their access to information that would propel them for the future (Nwokocha, 2016).

\section{THEORETICAL FRAMEWORK AND HYPOTHESES}

\subsection{Individual Innovativeness Theory}

The individual innovative theory is based on the personality attached to the adoption of innovation and the time the innovation was adopted (Hashim, 2008). The first category of adopters is innovator, the innovators are pioneers and risk takers who pave the way and adopts innovation with high uncertainty (Hashim, 2008). Early adopters make judicious and innovative decisions. The early majority interact frequently with peers and take far more innovative decision than the innovator and early adopters. Late majority adopts only when the innovation is adopted by others. Finally, Laggard makes resistant stance to the adoption of innovation (Hashim, 2008).

\subsubsection{Personal Learning Barriers in ICT among female students}

The Women's absence among the designers and creators of Information technology has a grievous consequence for the society. Women's underrepresentation in ICT sectors can be as a result of several factors such as geography, cultural factors, economy factors and race can be identified as having influence girls' career decision (Trauth, 2003). Although the external factors may not pose as stronger impediments than the personal factors as according to some authors, girls display a lower level of interest in ICT studies as compared to boys. In learning barriers, Pennacchia, Jones and Aldridge (2018) identified three types of learning barriers which include: situational, institutional and dispositional barriers. For the purpose of this study two of the learning barriers would be used which include situational and dispositional barriers. Situational barrier to learning arises from personal and family situations or circumstances while, dispositional barrier to learning arises from attitudes, expectation, motivations and perception of an individual (Pennacchia et al.,2018). This because many female students find ICT careers and studies boring and too technical. However, girls could develop interest for ICT based on their early exposure to ICT, ability to tackle mathematical questions and early exposure to computing subjects (Nwokocha, 2016). Additionally, Gebhardt, Fraillon, Ainley \& Schulz (2016) reported that globally that in 10 out of 14 countries, boys report more proficiency and experience in using computers than girls. The finding of Aifan (2016) showed that there were significant differences between males and females students in Saudi Arabia in the use of computers, males tend to be proficient in the usage and various tasks performed on computers than female students.

$\mathrm{HO}$ : There is no significant impact of learning barriers of female students on their ICT usage

\subsubsection{Determinants of ICT Adoption}

African girls are not well represented in Science and technology courses in secondary and tertiary institutions in the world. Studies conducted prove that girls 'interest on ICT education was as a result of their exposure and experience in ICT classes. Female students who develop a positive attitude towards ICT education are more likely to develop interest in it. While female students who do not are less likely to develop an interest in it. Derbyshire (2003) argues that the gender issue is being illuminated in a classroom where there are limited numbers of computers as it creates gender dichotomy as to who sits on the computer seat.

HO There is no significant impact of learning barriers and ICT usage of female students on their adoption strategy

\section{METHODOLOGY}

\subsection{Sample and Data Collection}

The target population for the study was female student of selected public secondary school in Ogun state. Ogun state was chosen because it has the highest number of public secondary schools as compared to 
other states in Nigeria. the study employed the simple random sampling method to select public secondary schools in Ogun state. Female students in JSS 3 and SS3 were randomly selected. The students from these categories (classes) were selected based the fact that it is the level at which students makes career choices concerning ICT. The study employed the survey research design. The sample size for the study was 150 female students from 3 public secondary schools drawn from the sample. 50 female students were selected from each of the public secondary school using the proportionate sampling method. Copies of Questionnaires were administered to the respondent to elicit their responses on the research issues.

Each questionnaire consists of four (4) parts. For the first part, it has the respondent's socio demographic data such as class, department, age, father's occupation and mother's occupation. The second part comprises of questions of ICT usage and frequency, questions such as how often do you use the internet were accompanied with answers like rarely=0, almost every day $=1$, about once a week $=2$, 1-2 times a month $=3$ and about 2-3 times a month $=4$. The third part involves learning barriers associated with ICT studies and fourth part involves adoption of ICT. The Cronbach's alpha of ICT adoption is 0.81 with 16 items, ICT usage is 0.89 with 12 items and learning barriers is 0.54 with 9items.

\section{STUDY FINDINGS}

Table 1.1 Descriptive Statistics

\begin{tabular}{|c|c|c|}
\hline ICT usage & Mean & Std. Deviation \\
\hline I write & 2.68 & 1.225 \\
\hline I play games & 2.88 & 1.154 \\
\hline I search for info on the internet & 2.58 & 1.163 \\
\hline for educational software to learn new things & 2.68 & 1.196 \\
\hline I do programming & 3.42 & .886 \\
\hline I use email & 3.16 & 1.075 \\
\hline I make films/animations on the computer & 3.45 & .887 \\
\hline I create/record sound files on the computer & 3.47 & .836 \\
\hline I use the internet to revise for exams & 3.01 & 1.147 \\
\hline I make/design things on the computer & 3.45 & .922 \\
\hline for school homework & 2.86 & 1.103 \\
\hline
\end{tabular}

\section{Figure 1}

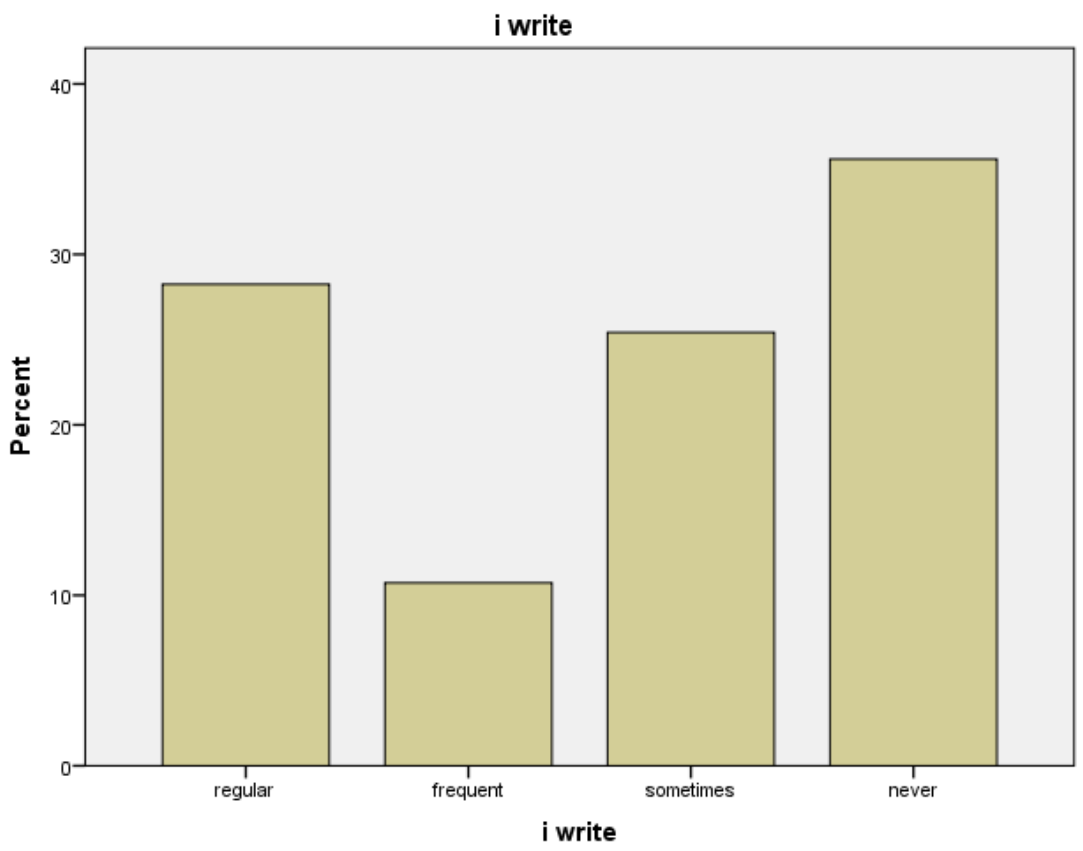

Figure 1 shows that percentage to which the computer was used by female respondents, $26.9 \%$ regularly, $10.2 \%$ frequently, $24.2 \%$ sometimes and $33.9 \%$ have never used the computer for writing. 


\section{Figure 1.2}

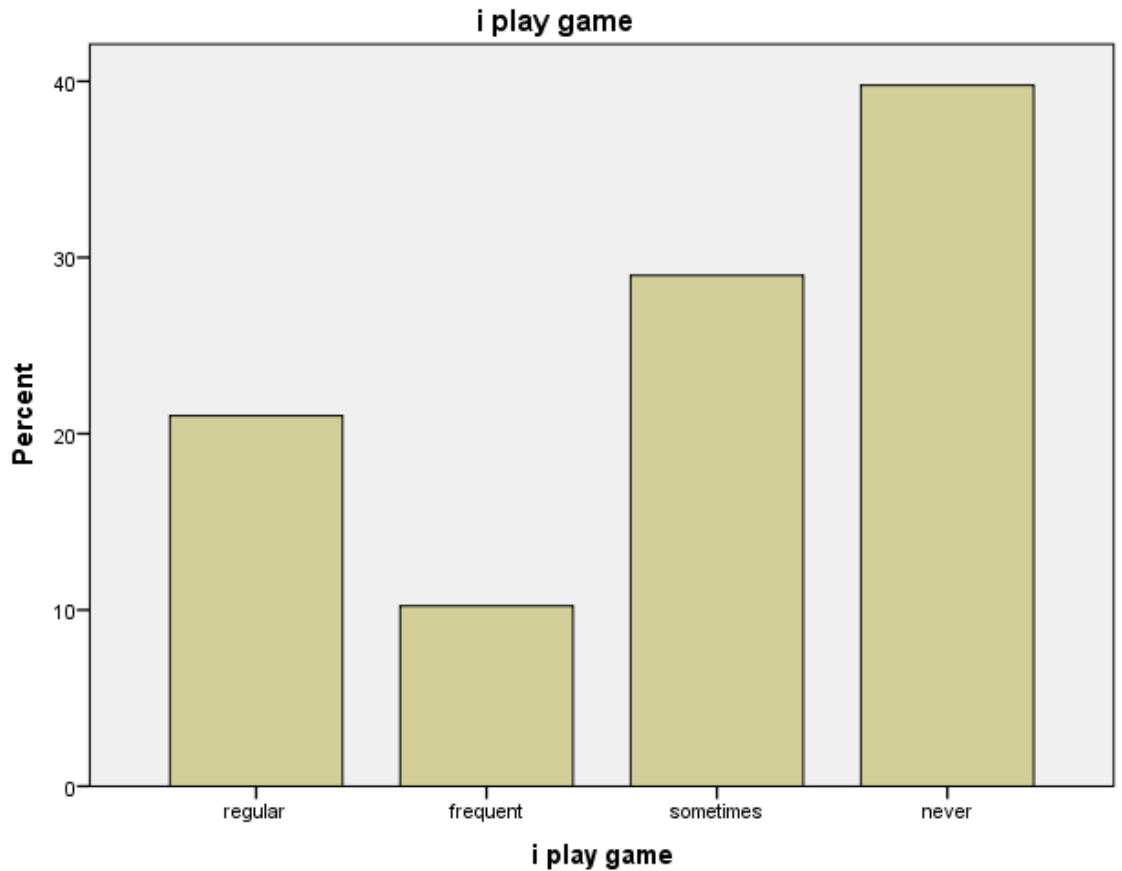

Figure 1.2 shows that percentage to which the computer was used by female respondents, $19.9 \%$ regularly, $9.7 \%$ frequently, $27.4 \%$ sometimes and $37.69 \%$ have never used the computer to play game.

\section{Figure 1.3}

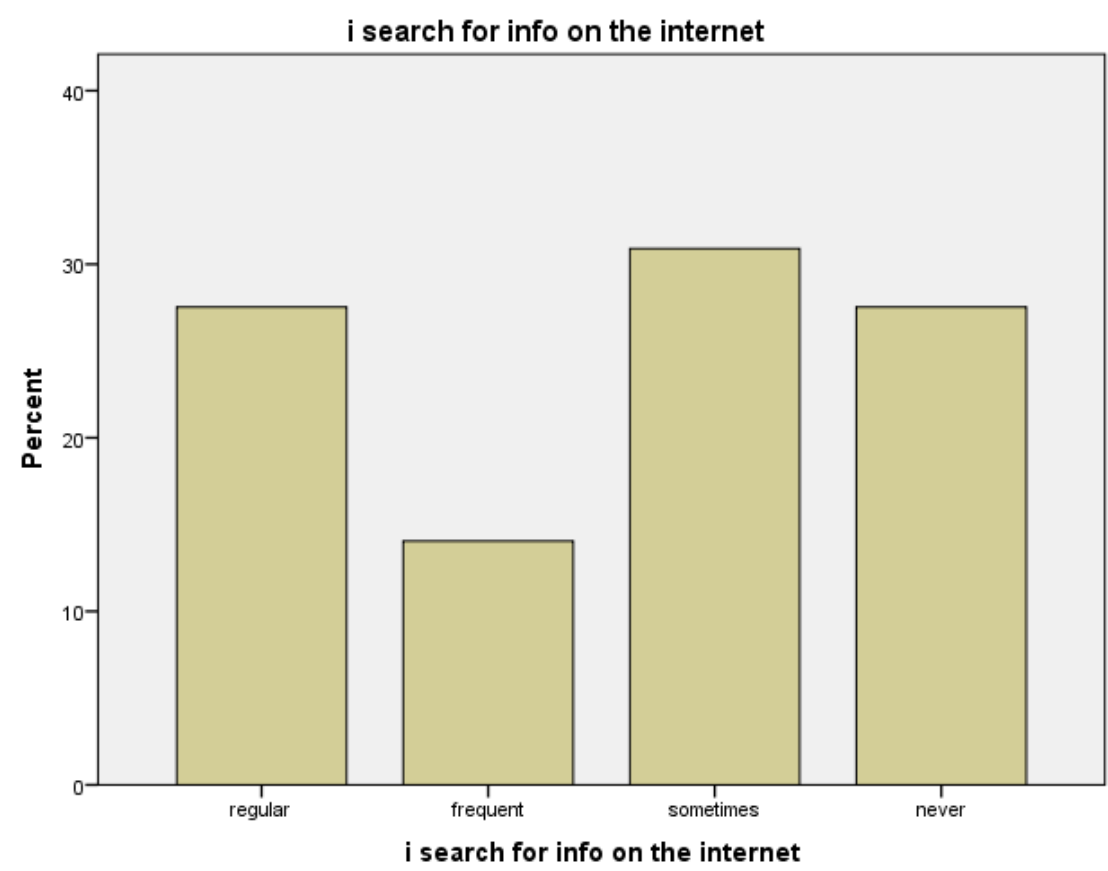

Figure 1.3 shows that percentage to which the computer was used by female respondents, $26.3 \%$ regularly, $13.4 \%$ frequently, $29.6 \%$ sometimes and $26.3 \%$ have never used the computer to search for information on the internet. 


\section{Figure 1.4}

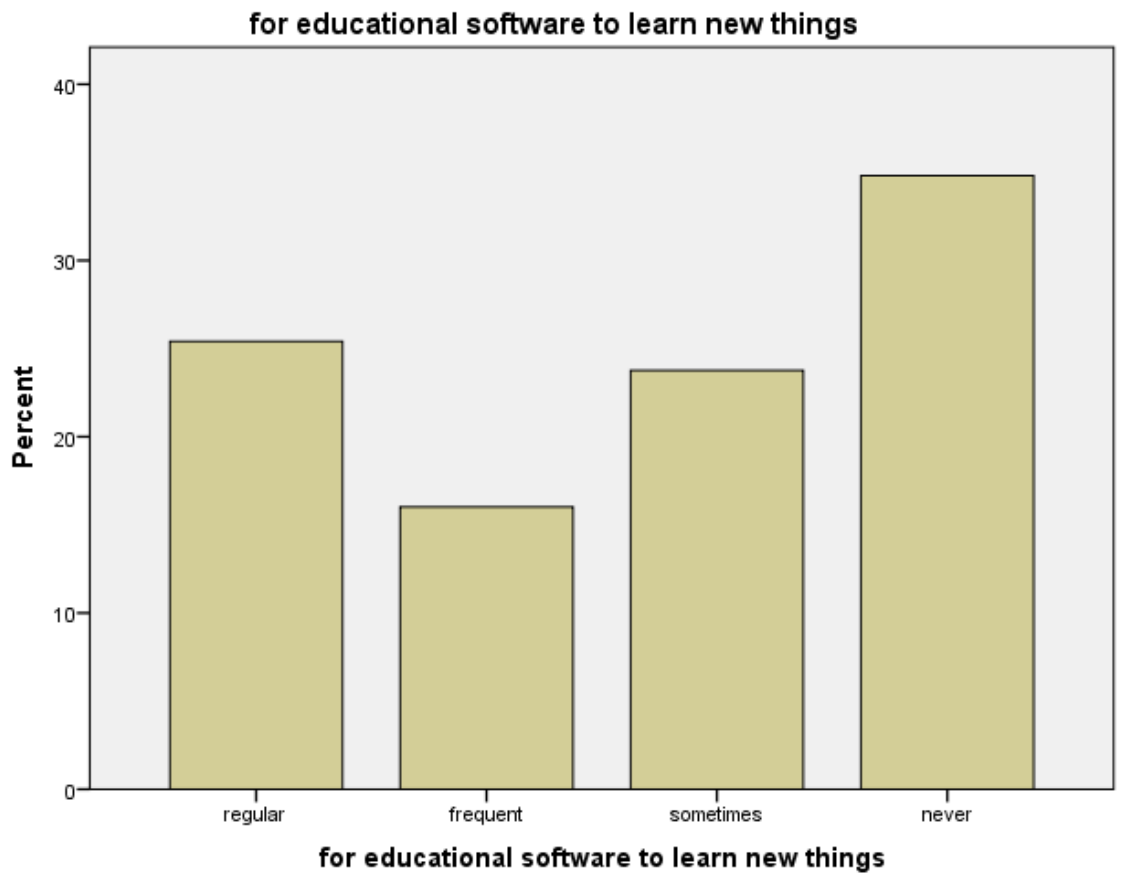

Figure 1.4 shows that percentage to which the computer was used by female respondents, $24.7 \%$ regularly, $15.6 \%$ frequently, $23.1 \%$ sometimes and $33.9 \%$ have never used the computer to learn new things.

\section{Figure 1.5}

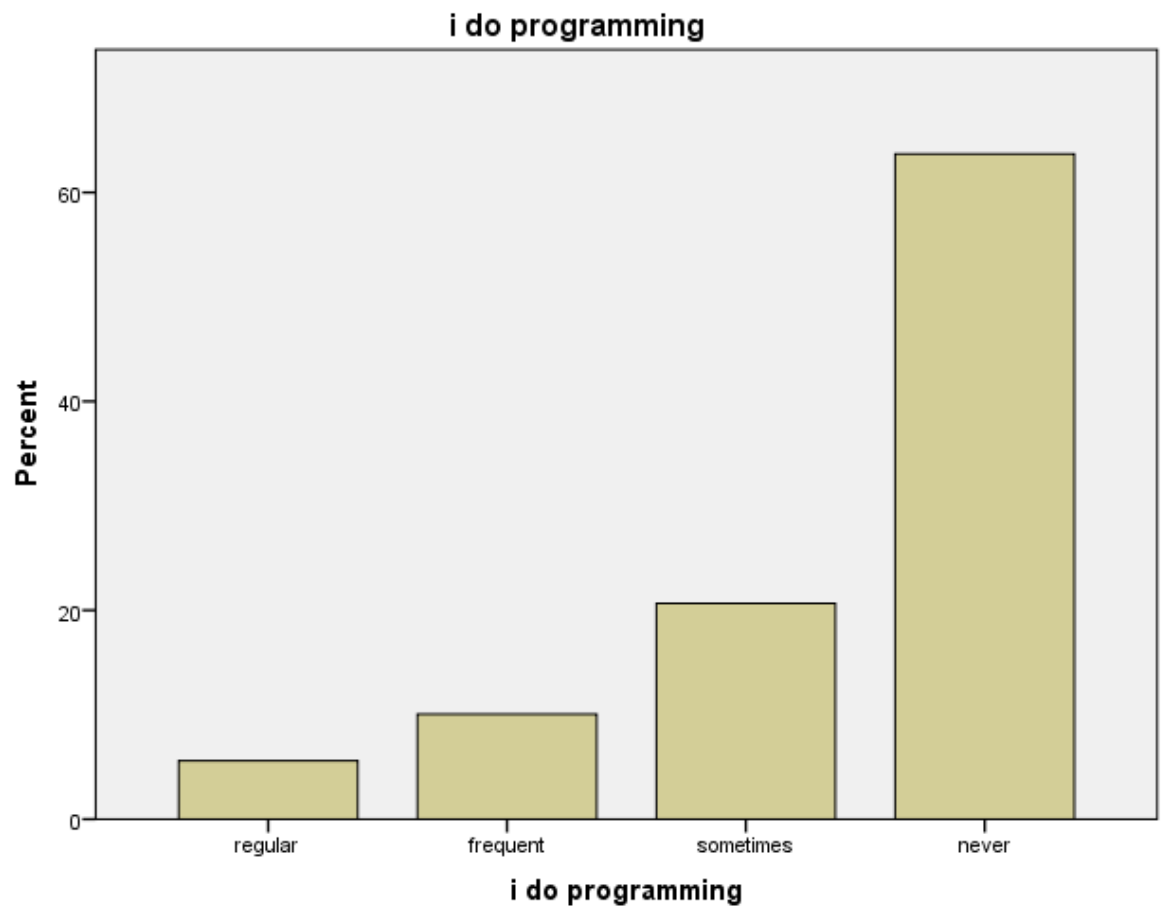

Figure 1.5 shows that percentage to which the computer was used by female respondents, $5.4 \%$ regularly, $9.7 \%$ frequently, $19.9 \%$ sometimes and $61.3 \%$ have never used the computer for programming. 


\section{Figure 1.6}

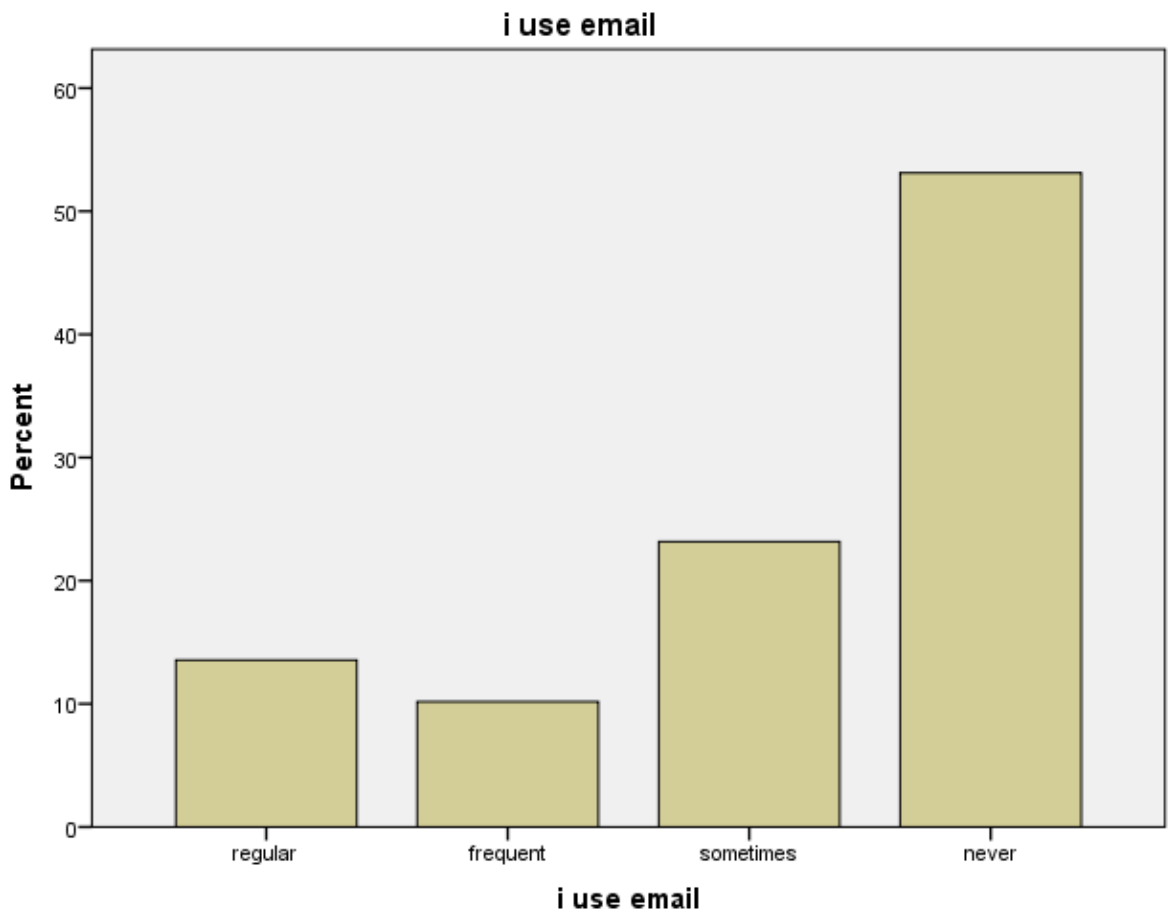

Figure 1.6 shows that percentage to which the computer was used by female respondents, $12.9 \%$ regularly, $9.7 \%$ frequently, $22.0 \%$ sometimes and $50.5 \%$ have never used the computer to send and receive email.

\section{Figure 1.7}

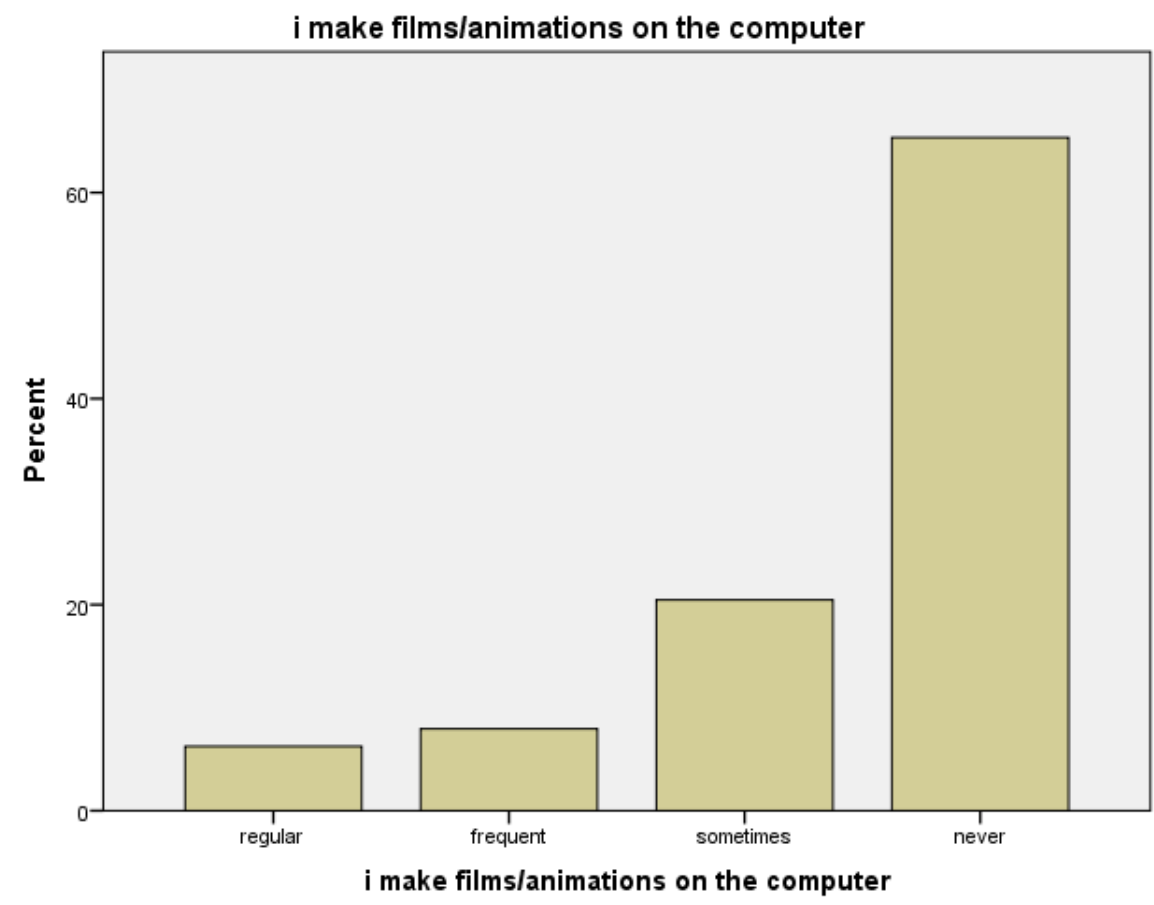

Figure 1.7 shows that percentage to which the computer was used by female respondents, $5.9 \%$ regularly, $7.5 \%$ frequently, $19.4 \%$ sometimes and $61,8 \%$ have never used the computer to make films and create animations. 


\section{Figure 1.8}

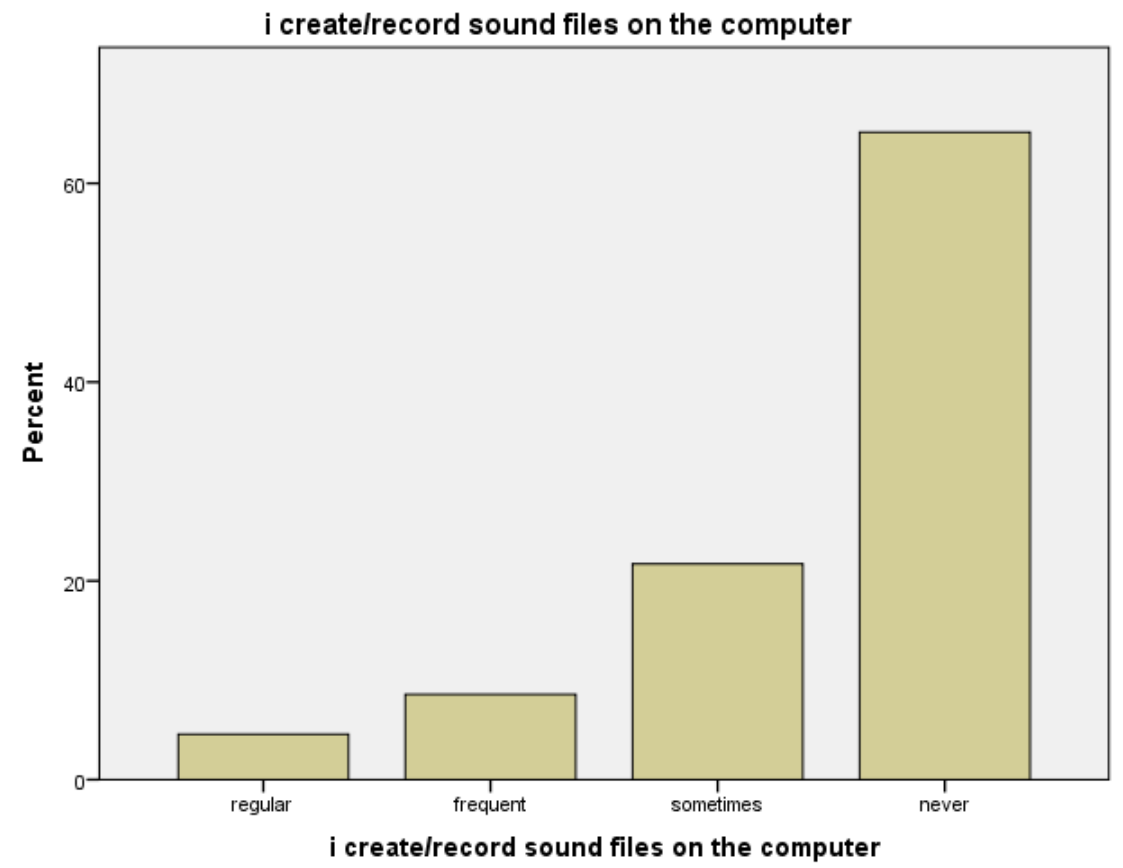

Figure 1.8 shows that percentage to which the computer was used by female respondents, $4.3 \%$ regularly, $8.1 \%$ frequently, $20.4 \%$ sometimes and $61.3 \%$ have never used the computer to create and record sound files on the computer.

\section{Figure 1.9}

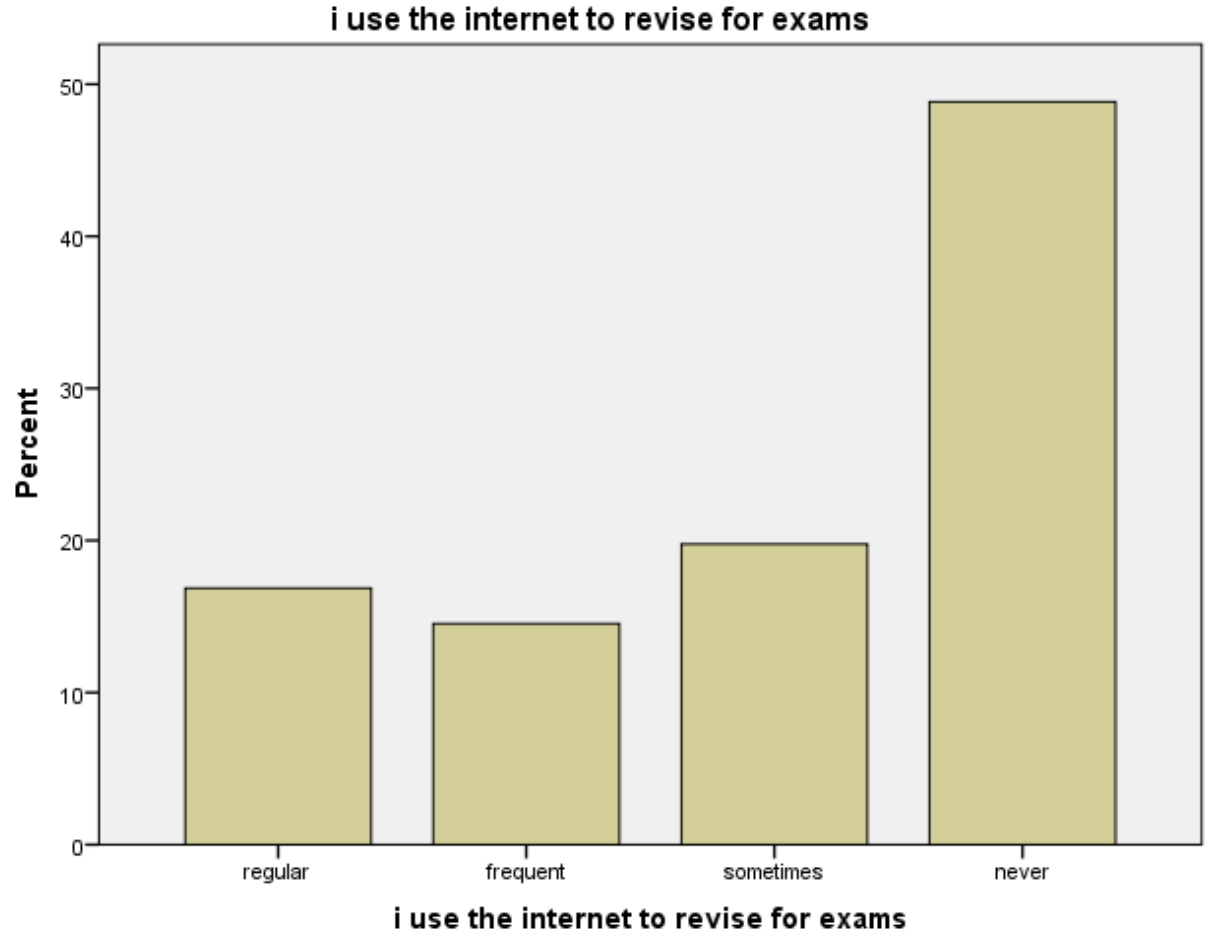

Figure 1.9 shows that percentage to which the computer was used by female respondents, $15.6 \%$ regularly, $13.4 \%$ frequently, $18.3 \%$ sometimes and $45.2 \%$ have never used the computer for exam revision. 


\section{Figure 2.0}

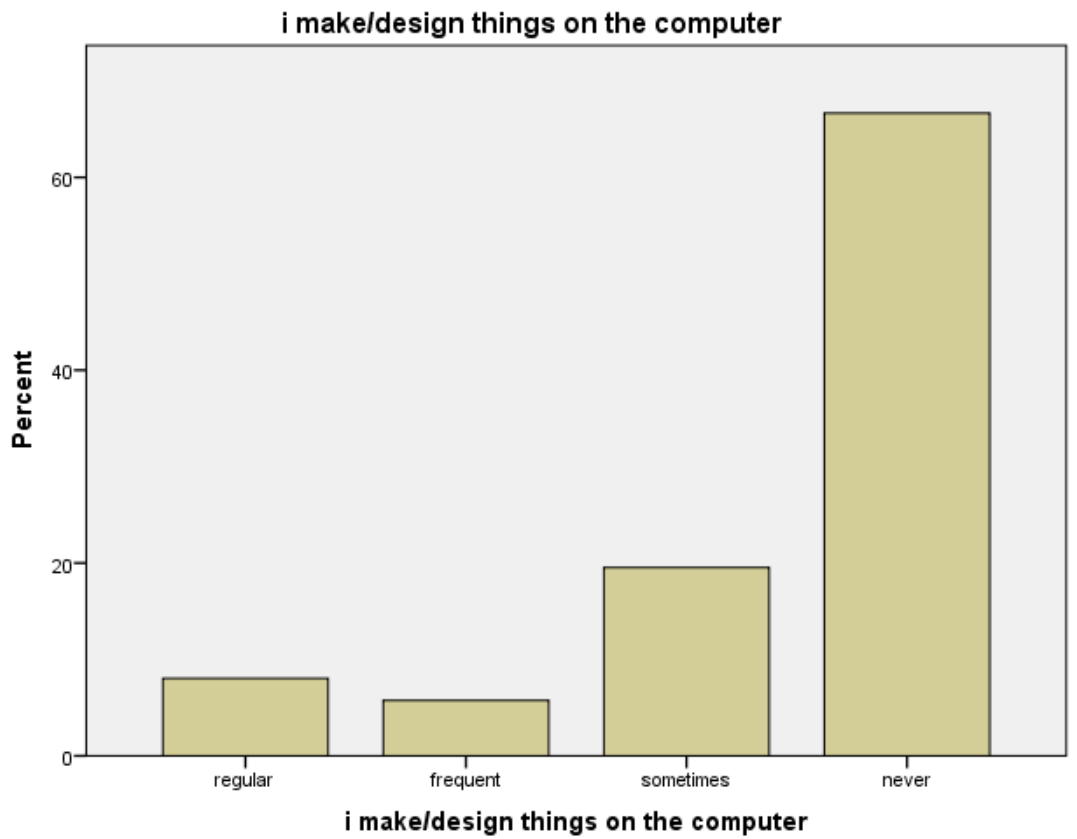

Figure 2.0 shows that percentage to which the computer was used by female respondents, $7.5 \%$ regularly, $5.4 \%$ frequently, $18.3 \%$ sometimes and $62.4 \%$ have never used the computer for design

\subsection{Individual innovativeness theory}

Table 1.2 Factor analyses for personal learning barriers of ICT studies

\begin{tabular}{|c|c|c|}
\hline \multicolumn{3}{|c|}{ Rotated Component Matrix ${ }^{a}$} \\
\hline \multirow[t]{2}{*}{ items } & \multicolumn{2}{|c|}{ Component } \\
\hline & Factor 1 & Factor 2 \\
\hline I will rather not have technology lessons at school & .536 & \\
\hline I do not have ICT studies mind & .566 & \\
\hline I find ICT studies confusing & .640 & \\
\hline I have never felt myself able to learn ICT studies & .712 & \\
\hline I find many ICT study problems challenging & & .765 \\
\hline I have never been very excited about ICT studies & .693 & \\
\hline $\begin{array}{l}\text { I have trouble learning how to use a computer than i do } \\
\text { learning other things }\end{array}$ & & .406 \\
\hline $\begin{array}{l}\text { when i have difficulties using a computer i know I can } \\
\text { handle them }\end{array}$ & & .496 \\
\hline $\begin{array}{l}\text { it takes me longer to understand computers than the } \\
\text { average person }\end{array}$ & & .624 \\
\hline $\begin{array}{l}\text { Extraction Method: Principal Component Analysis. } \\
\text { Rotation Method: Varimax with Kaiser Normalization. }\end{array}$ & & \\
\hline Rotation converged in 3 iterations. & & \\
\hline
\end{tabular}

In Table 1.2, 2 factors were extracted from 9 variables and a Varimax rotation was performed with the data. The strongest positive loading in factor 1 and factor 2 are "I have never felt myself able to learn ICT studies" (0.712) and "I find many ICT study problem challenging" (0.765). the variable with the strongest association to the underlying latent variable is the "I find many ICT study problems challenging" with a factor loading of 0.765 . 
Table 1.3 Factor analyses for the adoption of ICT

Rotated Component Matrixa

\begin{tabular}{|c|c|c|c|}
\hline & \multicolumn{3}{|c|}{ Component } \\
\cline { 2 - 4 } & 1 & 2 & 3 \\
\hline I will like to know more about technologies & & & .746 \\
\hline working in technology could be interesting & & .426 & .702 \\
\hline i will probably choose a job in technology & & .752 & \\
\hline i will like a career in technology later on & & .788 & \\
\hline with a technological job your job is promised & & .470 & .393 \\
\hline if there was a school club with technology will certainly join in & & .432 & .430 \\
\hline i enjoy repairing things at home & & & .559 \\
\hline my friends are interested in computers & .485 & & .387 \\
\hline when my friends and i get together we enjoy doing things on the & .754 & & \\
\hline computer & & & \\
\hline my friends and i like to help each other on the computer & .827 & \\
\hline my friends and i enjoy talking about computers & .738 & .582 & \\
\hline i will like to study computers in the university & & .672 & \\
\hline i enjoy talking to other people about computers & .672 & .322 & \\
\hline i enjoy the work i do in class & .649 & \\
\hline using computers is easy for me & .591 & \\
\hline i am confident in my ability to use computers & & \\
\hline \multicolumn{2}{|c|}{ Extraction Method: Principal Component Analysis. } \\
\hline \multicolumn{2}{|c|}{ a. Rotation converged in 4 iterations. } \\
\hline
\end{tabular}

\section{Notes- Factor1- Early majority, Factor 2-Innovator, Factor 3-Late majority}

In Table 1.3, 3 factors were extracted from 14 variables and a Varimax rotation was performed with the data. The strongest positive loading in factor 1 "I have never felt myself able to learn ICT studies" (0.649), in factor 2 "I would like a career in technology later on "I would like a career in technology later on "(0.788) and in factor 3 "I will like to know more about technology" (0.746). The variable with the strongest association to the underlying latent variable is the "I would like a career in technology later on "with a factor loading of 0.788 .

\subsection{Determinants of ICT adoption}

The impact of learning barrier and ICT usage on the Adoption strategy of ICT

Table 1.4 Model Summary

\begin{tabular}{|c|c|c|c|c|}
\hline Model & R & R Square & $\begin{array}{c}\text { Adjusted R } \\
\text { Square }\end{array}$ & $\begin{array}{c}\text { Std. Error of the } \\
\text { Estimate }\end{array}$ \\
\hline 1 & $.965^{\mathrm{a}}$ & .931 & .930 & .165 \\
\hline
\end{tabular}

a. Predictors: (Constant), learning barriers, ICT usage factors

The Regression model (which include learning barriers and ICT usage) explain 93 percent of the variance of adoption strategy

Table 1.5 ANOVAa

\begin{tabular}{|c|c|c|c|c|c|c|}
\hline \multicolumn{2}{|c|}{ Model } & $\begin{array}{c}\text { Sum of } \\
\text { Squares }\end{array}$ & df & Mean Square & F & Sig. \\
\hline \multirow{3}{*}{1} & Regression & 65.966 & 2 & 32.983 & 1212.156 & $.000^{\mathrm{b}}$ \\
\cline { 2 - 7 } & Residual & 4.898 & 180 & .027 & & \\
\cline { 2 - 7 } & Total & 70.863 & 182 & & & \\
\hline
\end{tabular}

a. Dependent Variable: adoption strategy

b. Predictors: (Constant), learning barriers, ICT usage 
The Anova result reveals that learning barriers and ICT usage explains adoption strategy of the female respondents. The result as presented in Table 1.5 shows that the impact of learning barriers and ICT usage on adoption strategy of female respondents' $F(2,180)=1212.156, P=0.000$ that is $p<0.0005)$. hence the result of the model is statistically significant.

Table 1.6 Coefficients ${ }^{\mathrm{a}}$

\begin{tabular}{|c|c|c|c|c|c|c|}
\hline \multicolumn{2}{|c|}{} & \multicolumn{2}{|l|}{ Unstandardized Coefficients } & $\begin{array}{c}\text { Standardized } \\
\text { Coefficients }\end{array}$ & \multirow{2}{*}{ Sig. } & \\
\cline { 3 - 7 } \multicolumn{2}{|c|}{} & B & Std. Error & Beta & & \\
\hline \multirow{2}{*}{1} & (Constant) & .057 & .055 & & 1.041 & .299 \\
\cline { 2 - 7 } & ict usage factors & .005 & .015 & .007 & .325 & .746 \\
\cline { 2 - 7 } & learning barriers & .972 & .020 & .963 & 47.884 & .000 \\
\hline
\end{tabular}

Between the two variables, the learning barrier is statistically significant in explaining adoption strategy of female respondents $(P=0.000)$ when $p$ value $<0.05$. a 0.963 -unit increase in learning barriers would lead to an increase unit in adoption strategy. Based on the hypothesis stated that there is no significant impact of learning barriers and ICT usage of female students on their adoption strategy, the above findings reject the null hypothesis and accept the alternative hypothesis that there is a significant

\subsection{Learning barriers in ICT among female students}

Table 1.7 Model Summary

\begin{tabular}{|c|c|c|c|c|}
\hline Model & $\mathbf{R}$ & R Square & Adjusted R Square & Std. Error of the Estimate \\
\hline 1 & $.226^{\mathrm{a}}$ & .051 & .046 & .60422 \\
\hline
\end{tabular}

a. Predictors: (Constant), ICT usage factors

The Regression model (which include ICT usage) explain 0.51 percent of the variance of learning barriers

Table 1.8 ANOVAa

\begin{tabular}{|l|c|c|c|c|c|c|}
\hline \multicolumn{2}{|c|}{ Model } & Sum of Squares & df & Mean Square & F & Sig. \\
\hline 1 & Regression & 3.571 & 1 & 3.571 & 9.780 & $.002^{\text {b }}$ \\
\cline { 2 - 7 } & Residual & 66.080 & 181 & .365 & & \\
\cline { 2 - 7 } & Total & 69.650 & 182 & & & \\
\hline
\end{tabular}

a. Dependent Variable: learning barriers

b. Predictors: (Constant), ICT usage

The Anova result reveals that learning barriers explains ICT usage of the female respondents. The result as presented in Table 1.8 shows that the impact of ICT usage on learning barriers of female respondents' $F(1,181)=9.780, P=0.002$ that is $p<0.005)$. hence the result of the model is statistically significant. 
Table 1.9 Coefficientsa

\begin{tabular}{|c|c|c|c|c|c|c|}
\hline & \multirow[b]{2}{*}{ Model } & \multicolumn{2}{|c|}{$\begin{array}{l}\text { Unstandardized } \\
\text { Coefficients }\end{array}$} & \multirow{2}{*}{$\begin{array}{c}\begin{array}{c}\text { Standardized } \\
\text { Coefficients }\end{array} \\
\text { Beta }\end{array}$} & \multirow[b]{2}{*}{$\mathrm{t}$} & \multirow[b]{2}{*}{ Sig. } \\
\hline & & B & Std. Error & & & \\
\hline \multirow[t]{2}{*}{1} & (Constant) & 3.554 & .169 & & 21.010 & .000 \\
\hline & ict usage & -.170 & .054 & -.226 & -3.127 & .002 \\
\hline
\end{tabular}

ICT usage is statistically significant in explaining learning barriers of female respondents $(P=0.002)$ when $p$ value <0.05. a 0.226-unit increase in ICT usage would lead to a decrease unit in learning barriers. Based on the hypothesis stated that there is no significant impact of learning barriers of female students on their ICT usage, the above findings reject the null hypothesis and accepts the alternative hypothesis that there is a significant impact of ICT usage of female students on learning barriers.

\section{DISCUSSION OF FINDINGS}

The purpose of the study is to seek to examine the learning obstacles and adoption associated with ICT usage among female students in public secondary schools in Ogun state, Nigeria. Established on the findings, ICT usage has a significant impact on the learning barriers of female respondents. Previous studies have shown the impact of ICT to facilitate the knowledge and skills of the girl-child, as well as increasing girl-child interest in science and technology and entrance to knowledge-based society (Ogundele et al., 2019). According to the findings the two learning barriers by female students associated with the use of computers were the situational barriers and the dispositional barriers which was based on Pennacchia, Jones and Aldridge (2018) classification of learning barriers.

The findings also reported that learning barriers as an impact on the adoption strategy. This implies that the more learning barriers female students is likely to encounter as regards to the use of computers, the more strategy they are likely to adopt. Female students who develop a positive attitude towards ICT education are more likely to adopt it. While respondents who do not are less likely to develop an interest in it. The findings also indicated that majority of the respondents rarely make use of computers, this occasional use of computer has an impact on the learning barriers and adoption strategy of the respondents. Respondents who rarely make use of the computer is likely to be faced with learning barriers associated with ICT.

Based on the theory employed for the study, three personalities were identified based on the items early majority, innovator and late majority. According to Hashim (2008) the early majority interact frequently with peers and take far more innovative decision than the innovator and early adopters, based on the findings, respondents develop interest in the usage of computer as a result of their interaction with peers. Respondents who are in the category of Late majority only used the computers because of external influence and interest. Finally, respondents who are under the category of innovators were more likely to adopt the use of computer and also venture into a profession in ICT despite its uncertainty as Hashim (2008) describes the innovators are creators and risk takers who creates way and adopts innovation with high uncertainty.

\section{CONCLUSION AND RECOMMENDATION}

The findings of this study prove the existence of learning barriers of ICT studies among female students in public secondary schools in Ogun state. The findings revealed the low usage of computers for learning. The findings also show that the learning barriers of the female students determine what their adoption strategy of ICT. The learning barriers which female students faced in ICT studies can be reduced by the constant usage of ICT, although, the findings indicated that majority of the female students use computers on rare occasions. Consequently, the occasion use of computers has a major impact on learning barriers and adoption strategy of the female students.

Government should ensure that ICT facilities are provided to school. ICT policy should be implemented properly to eradicate personal learning barriers associated with the use of computer as ICT education would be made compulsory for all students in secondary schools. Schools should encourage and promote ICT education to the girl-child at their formative years. When a girl-child is exposed to ICT education at an early stage, most especially in primary school, she develops interest and positive attitude towards the adoption of 
ICT in her later life.

\section{REFERENCE LIST}

Adomi, E. and Kpangban, E. (2010). Application of ICTs in Nigerian Secondary Schools. Library Philosophy and practice (e-journal).

Aifan, H.A. (2016). Gender differences in terms of the experiences that Saudi Students have with social media technologies. Global Advanced Research Journal of Educational Research and Review 5(5): 071-073,

Ajayi, I. A. and Ekundayo, H. T. (2009). The Application of Information and Communication Technology in Nigeria Secondary Schools. International NGO journal, Vol.4, No.5, pp. 281-286

Damkor, M., Irinyang, D. and Manasseh, H. (2015). The Role of Information Communication Technology in Nigeria Educational System, Vol.2, Iss 2, pp. 64-68

Derbyshire, H. (2003). Gender issues is the use of computer in education in Africa. Imfundo. Partnership for IT in education.

Gebhardt, E., Fraillon, J., Ainley, J. \& Schulz, W. (2016) Gender Differences in computer and Information Literacy and the Use of ICT. A thematic report from the IEA International Computer and Information Literacy Study. IEA General Assembly Meeting 57 10-13 October 2016, Oslo, Norway

George, T. O and Ahmadu, F. O. and Chukwuedozie, O. (2013). ICT and Secondary School Educational System in Nigeria: A Conceptual Review. In: A Panoply of Readings in Social Sciences. Department of Sociology College of Development Studies Covenant University Ota, Nigeria.

George T. O \& Barnabas S. (2015), ICT and the Gender Question: Prospects and Challenges for the Knowledge Economy in the $21^{\text {st }}$ Century. International conference on Africa development issues (CUICADI). Covenant University, Ota, Nigeria.

Hashim, J. (2008). Learning Barriers in Adopting ICT among selected Working Women in Malaysia. Gender in Management, Vol.23, No.5, pp.317-336.

Ilo, P. I., Idiegbeyan-ose, J., Fagbohun, M. and Osinulu, I. (2018). The impact of Information and Communication Technology (ICT) on the habits of students of Iganmode Grammar School, Ota, Ogun state. Library Philosophy and practice (e-journal).

Nwokocha, E. T. (2016). Bridging the Barriers: ICT in the Girl-child Education in Nigeria. Developing Country Studies, Vol. 6, No.10, pp44-51.

Odukoya, A. (2005). ICT and women: Engendering the Information ociety in Nigeria. Development Information Network. Lagos: A DevNet Publication.

Ogundiile, O. P., Bishop, S. A., Okagbue, H. I., Ogunniyi, P. O. and Olanrewaju, A. M. (2019). Factors influencing ICT adoption in some selected Secondary Schools in Ogun State, Nigeria. International Journal of Emerging Technology in Learning, Vol.14, Iss 10, pp.62-74.

Olubebe, N. P. (2006). Appraising the relationship between the ICT usage and integration and the standard of teacher education programs in a developing economy. International Journal of Education and Development using Information and Computer Technology (IJEDICT), Vol.2, issue 3, pp.70-85.

Pennachhia, J., Jones E. and Aldridge, F. (2018).Barriers Toleraning for Disadvantaged groups. Report of Qualitative Findings August 2018.

Tayo O. George, Anthony C. Onwumah, Micheal Fagbohun, Mercy Adebayo \& Olawale Olonade (2019). "Gender Differences in ICT Studies: A Study of Selected Public Secondary Schools in Ogun Stae, Nigeria" in Gender Gaps and Social Inclusion Movement in ICT edited by Idongesit Williams, Olga Millward and Roselyn Layton published by IGI Global USA Pages 147-169,. Scopus Indexed.

Trauth, E. M. (2003). Diversity, Gender and the IT Profession. Gender and IT Workshop, University of Salford, Manchester, UK. 